This item was submitted to Loughborough's Institutional Repository (https://dspace.lboro.ac.uk/) by the author and is made available under the following Creative Commons Licence conditions.

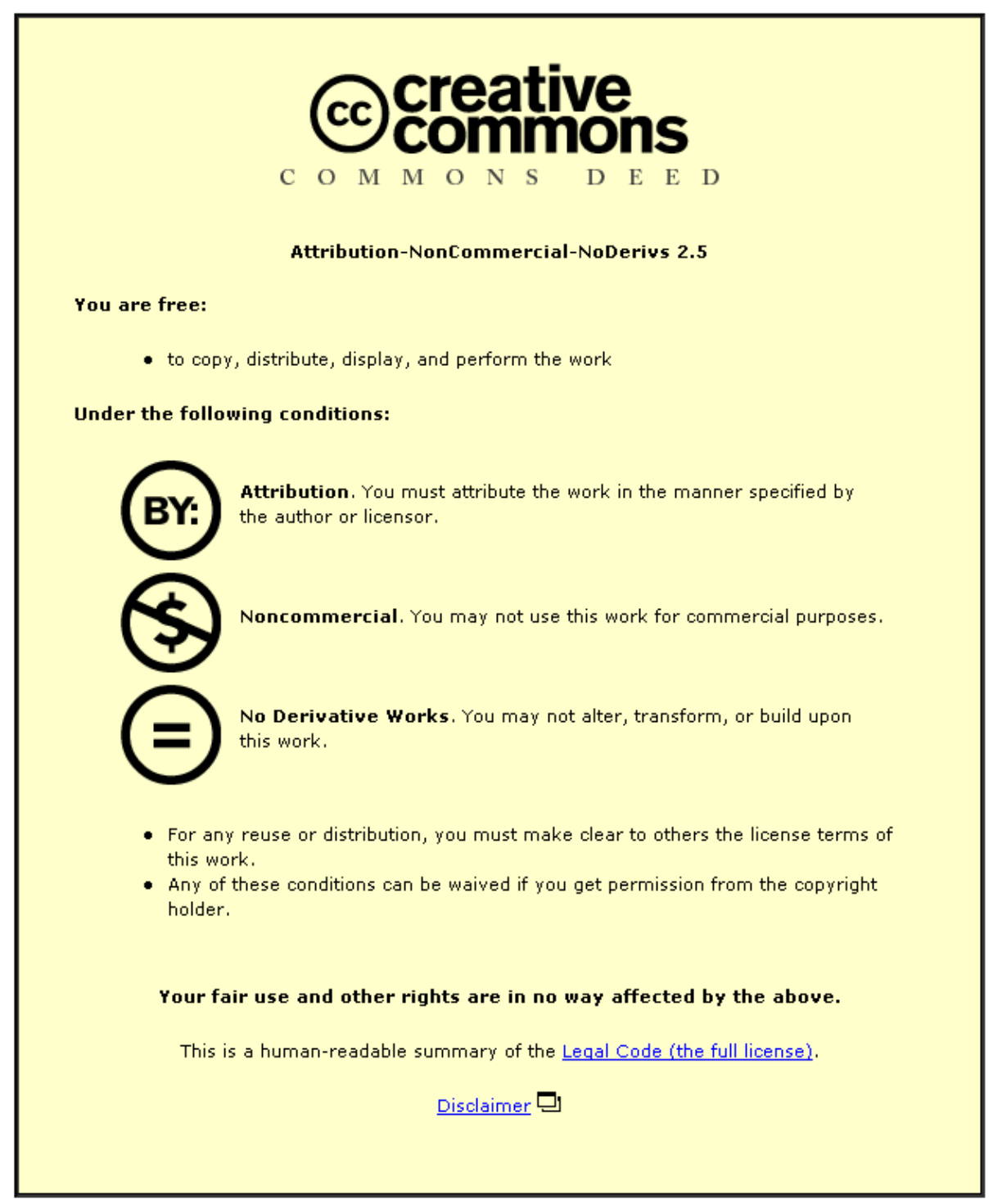

For the full text of this licence, please go to: http://creativecommons.org/licenses/by-nc-nd/2.5/ 


\title{
Electroless Ni-W-P Alloys as Barrier Coatings for Liquid Solder Interconnects
}

\author{
K.Chen, C. Liu, D.C. Whalley and D.A. Hutt, \\ Wolfson School of Mechanical and Manufacturing Engineering, \\ Loughborough University, Loughborough, LE11 3TU, UK \\ Email: K.Chen@lboro.ac.uk
}

J.F. Li, and S.H. Mannan

Department of Mechanical Engineering, King's College London, Strand, London WC2R 2LS, UK

\begin{abstract}
The control of the interfacial reaction rate is of great importance for liquid solder interconnects for high temperature electronic assemblies. Conventional electroless Ni-P barrier metallizations have been found to be inadequate for providing long term protection of the underlying metallization from the attack of molten solders. In this paper, binary Ni-P was modified with the co-deposition of a refractory alloying element, tungsten $(W)$, from its soluble metal salt added to the plating bath. Critical parameters for the deposition of ternary Ni-W-P were identified. The long term reaction between $N i-W-P$ and molten Sn-Bi solder at $200{ }^{\circ} \mathrm{C}$ was studied. The results indicated that $N i-W$-P barrier coatings with higher $W$ contents have much longer service lifetime as a barrier than normal Ni-P coatings. A mechanism for the reaction between Ni-W-P and molten $\mathrm{Sn}$-Bi solder, and a failure mechanism for the $\mathrm{Ni}-\mathrm{W}$-P layer, are also proposed.
\end{abstract}

\section{Introduction}

Liquid solder interconnects are promising as a new soldering technology for high temperature electronics [1]. As the solder is designed to operate in the liquid state as compared to the solid state of conventional solders, one of the fundamental challenges for liquid solder interconnects is to maintain the microstructural stability of the interface between the molten solder and the metallization of substrate or components. For typical metallizations, this interface deteriorates due to the growth of substantial quantities of intermetallic compounds (IMC) resulting from the rapid reaction between the solder and the contact metallizations at high operating temperatures. One way to slow down the liquid state interfacial reaction is by adding a special inhibitor additive into the solder alloy. However, it has been found that amongst a broad range of additional elements studied, some limited success has only been achieved with the addition of copper to the eutectic Sn-Bi solder [2], which is the most suitable low melting solder for liquid solder applications. Al has also been reported as a suitable inhibitor [1], but has only been tested successfully under vacuum conditions, and interferes with solder wetting in air. The other approach to suppress the interfacial reaction is to deposit a barrier layer on the surface of the metallization. It is reported that refractory metals like niobium and tungsten have excellent barrier properties in contact with molten solder and only very slow and limited growth of IMCs are observed [3]. However, these refractory metals cannot be deposited alone from aqueous solution by cost-effective electroplating or electroless plating techniques.

In this paper, an alternative approach to control the interfacial reaction was studied by introducing the refractory metal element, tungsten, into the conventional electroless Ni-P metallization. The electroless Ni-W-P alloys thus obtained were subjected to reaction with molten $\mathrm{Sn}-58 \mathrm{Bi}$ solder at $200{ }^{\circ} \mathrm{C}$ for up to two months. The reaction behaviours of electroless Ni-W-P alloys after different reaction time were then characterized.

\section{Experimental}

The electrolyte formulations for the deposition of electroless Ni-W-P alloys are given in Table 1, in which sodium tungstate was used as the source of $\mathrm{W}$. The solution was made up with deionised water. Variations in the $\mathrm{pH}$ value and plating temperature of Solution A were made to examine the effects on the deposit composition and the reactivity with molten Sn-Bi solder of Ni-W-P alloys. Solution B was used to deposit Ni-W-P with a high tungsten content [4].

For the preparation of substrate materials, copper panels $(250 \mu \mathrm{m}$ thick) were first cut into $5 \times 5 \mathrm{~mm}$ squares. Before plating, these copper samples were pickled in a solution containing $500 \mathrm{ml} \mathrm{HNO}_{3}$ (S.G. 1.42) and $500 \mathrm{ml}$ deionised water for 30 seconds to remove oxides on the surface. After thorough rinsing in tap water and deionised water, the copper samples were sensitized for 2 minutes at room temperature in a solution containing $10 \mathrm{~g} / 1 \mathrm{SnCl}_{2}$ and $40 \mathrm{ml} / 1 \mathrm{HCl}$ (S.G. 1.18) and then activated (1 minute) in a $20 \mathrm{ml} / \mathrm{l}$ 
$\mathrm{HCl}$ solution that contained $0.2 \mathrm{~g} / 1 \mathrm{PdCl}_{2}$. To study the effect of substrate materials, electroless Ni-W-P alloys were also deposited onto aluminium (Al) substrate. The details of the pre-treatment for the electroless plating on $\mathrm{Al}$ can be found in [5].

Table 1: Solution formulation and plating conditions for electroless Ni-W-P

\begin{tabular}{lcc}
\hline & Solution A & Solution B \\
\hline $\mathrm{NiSO}_{4} \cdot 6 \mathrm{H}_{2} \mathrm{O}$ & $26 \mathrm{~g} / \mathrm{l}$ & $7 \mathrm{~g} / \mathrm{l}$ \\
$\mathrm{Na}_{2} \mathrm{WO}_{4} \cdot 2 \mathrm{H}_{2} \mathrm{O}$ & $33 \mathrm{~g} / 1$ & $35 \mathrm{~g} / 1$ \\
$\mathrm{NaH}_{2} \mathrm{PO}_{2} \cdot \mathrm{H}_{2} \mathrm{O}$ & $12 \mathrm{~g} / \mathrm{l}$ & $10 \mathrm{~g} / 1$ \\
$\mathrm{Na}_{3} \mathrm{C}_{6} \mathrm{H}_{8} \mathrm{O}_{7} \cdot 2 \mathrm{H}_{2}$ & $75 \mathrm{~g} / 1$ & $40 \mathrm{~g} / 1$ \\
$\mathrm{O}$ & & \\
$\mathrm{pH}$ & $7.0-9.0$ & 8.2 \\
Temperature & $80-95^{\circ} \mathrm{C}$ & $90^{\circ} \mathrm{C}$ \\
\hline
\end{tabular}

After electroless plating, the Ni-W-P coated copper samples were thoroughly rinsed and dried in a hot air stream. Approximately $0.1 \mathrm{ml}$ of $\mathrm{Sn}-\mathrm{Bi}$ solder paste was dispensed manually using a syringe onto each of the samples. The samples were then reflowed in air at $260{ }^{\circ} \mathrm{C}$ for 5 minutes. The solder joints thus formed had a semi-spherical profile with a maximum thickness of about $1 \mathrm{~mm}$ at the top of the solder dome. Following ultrasonic cleaning in acetone and deionised water to remove flux residues, the reflowed samples were stored in an oven at 200 ${ }^{\circ} \mathrm{C}$ for various periods in order to allow the Ni-W-P deposits to react with the molten Sn-Bi solder.

The interfacial microstructure of the Ni-W-P/Sn$\mathrm{Bi}$ solder joints after the high temperature storage and cross-sectioning was examined using a Scanning Electron Microscope (SEM). The composition of both the Ni-W-P deposits and the different phases at the interface was analyzed using energy dispersive $\mathrm{X}$-ray microanalysis (EDX) incorporated in the SEM.

\section{Results and discussion}

\section{Characteristics of $\mathrm{Ni}-\mathrm{W}-\mathrm{P}$}

It was found from our preliminary investigation that the barrier properties of Ni-W-P alloys on reaction with molten $\mathrm{Sn}-\mathrm{Bi}$ solder are sensitive to variations in the plating conditions. Although Ni-W$\mathrm{P}$ (on Al) from Solution A has been found to be able to survive storage at $200-240{ }^{\circ} \mathrm{C}$ for at least one month without solder penetration [6], Ni-W-P deposited on $\mathrm{Cu}$ from a second bath with small changes to increase the bath stability was penetrated
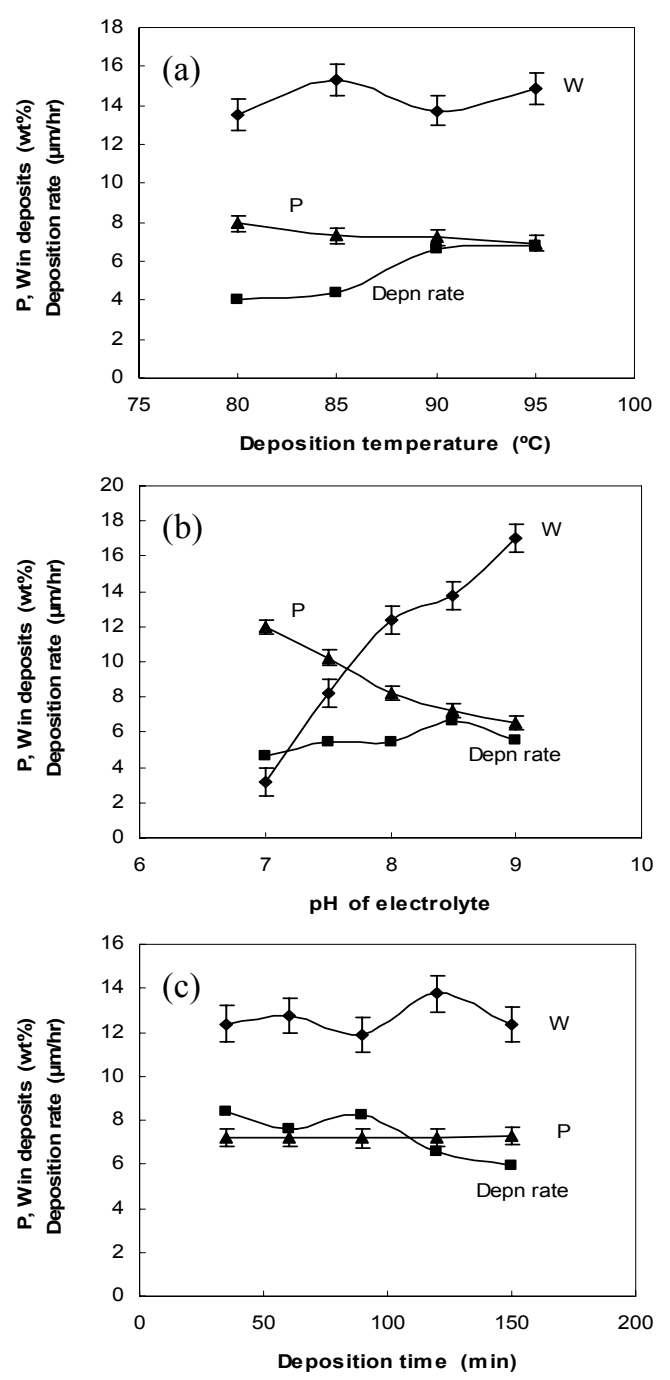

Figure 1 Effect of plating parameters on the chemical composition and deposition rate of Ni-W-P from Solution A. (a) Effect of solution temperature. $\mathrm{pH}$ 8.5; (b) Effect of $\mathrm{pH}$. Temperature $90^{\circ} \mathrm{C}$; (c) Effect of deposition time. $\mathrm{pH} 8.5$ and temperature $90{ }^{\circ} \mathrm{C}$

by molten $\mathrm{Sn}-\mathrm{Bi}$ in less than 48 hours. It is therefore important to understand the effect of plating parameters on the characteristics of the resulting NiW-P layer in order to maintain the reproducibility of its good barrier properties.

To begin with, an assessment was made of the influence of plating parameters on the chemical composition and deposition rate of Ni-W-P alloys deposited on $\mathrm{Cu}$ substrates from Solution A. As shown in Figure 1(a), the deposition temperature did not have a significant influence on the $\mathrm{P}$ and $\mathrm{W}$ content in the deposits obtained, although the deposition rate, which is an average over the plating time of 2 hours, increased with increasing temperature. On this basis, a solution temperature of $90{ }^{\circ} \mathrm{C}$ was thus maintained in the following studies. 
The effect of the $\mathrm{pH}$ value of the plating solution is shown in Figure 1(b). It can be seen that there is a marked increase in the $\mathrm{W}$ content and an apparent decrease in the $\mathrm{P}$ content in the deposits with increasing $\mathrm{pH}$ value. For the variation of deposition rate with $\mathrm{pH}$, it seemed that a maximum deposition rate was achieved at $\mathrm{pH}$ 8.5. Such results are in agreement with Aoki et al's findings from studies within a wider range of $\mathrm{pH}$ values (5-10) [7]. The increased $\mathrm{W}$ at higher $\mathrm{pH}$ values may be due to the increased reduction ability of the reducing agent (sodium hypophosphite) [5], whilst the decrease in the deposition rate at $\mathrm{pH} 9$ may be attributed to the increased stability of the citrate complex with nickel ions with increasing $\mathrm{pH}$. Since the solution with too high a $\mathrm{pH}$ is not stable and susceptible to spontaneous decomposition, $\mathrm{pH} 8.5$ was determined to be the most suitable value for the subsequent experiments. The significant effect of $\mathrm{pH}$ value on the Ni-W-P deposits means that a careful and close control over the solution $\mathrm{pH}$, both during the solution make-up process and the actual plating, is required. The latter is particularly important since $\mathrm{pH}$ would decrease gradually with prolonged deposition time as a result of the side-reaction of hydrogen evolution.

The variation of Ni-W-P deposition behaviour with deposition time is of concern since it determines the depth profile of deposit composition and therefore the consistency of the reaction of $\mathrm{Ni}$ $\mathrm{W}-\mathrm{P}$ coatings with prolonged exposure to molten solder. It can be seen from Figure 1(c) that although the deposition rate of Ni-W-P decreases gradually with increasing deposition time, the $\mathrm{W}$ and $\mathrm{P}$ content in the coating remains relatively constant. This result corresponds well with the later compositional analysis on the cross-section, which shows that the deposition composition of Ni-W-P obtained in this study is uniform through the whole thickness.

The surface morphology of electroless Ni-W-P alloys is shown in Figure 2. Like electroless Ni-P coatings, the surface of Ni-W-P has a nodular characteristic with different sizes. There were also observed a large number of nano-sized pin-holes or small pores in the Ni-W-P along the nodule boundaries, as indicated by arrows on Figure 2(a). These defects were believed to be caused by hydrogen bubbles adsorbing on the deposit surface. Although it is not clear what effects these defects have on the barrier properties of Ni-W-P, some efforts were made to prepare pore-free coatings. An anionic surfactant, sodium lauryl sulphate (SLS),
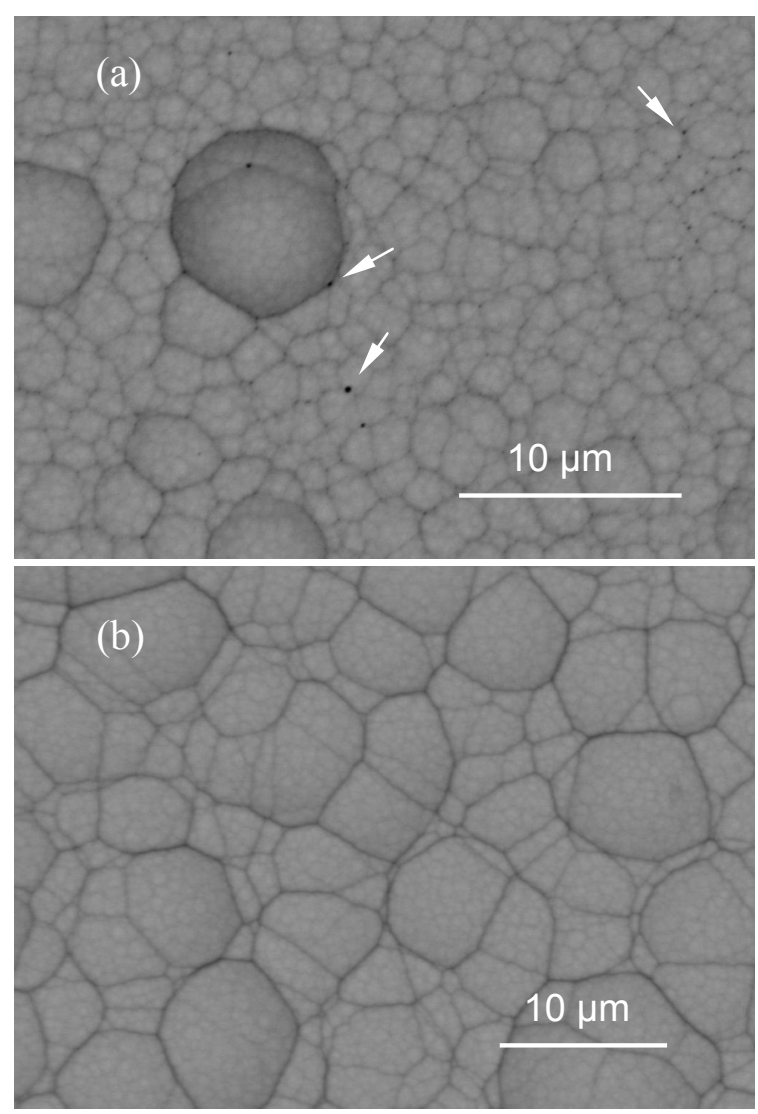

Figure 2: Micrographs showing the surface morphology of Ni-W-P from Solution A, $\mathrm{pH} \mathrm{8.5,} 90^{\circ} \mathrm{C}$.

(a) no additives; (b) addition of $0.3 \mathrm{mg} / 1 \mathrm{SLS}$

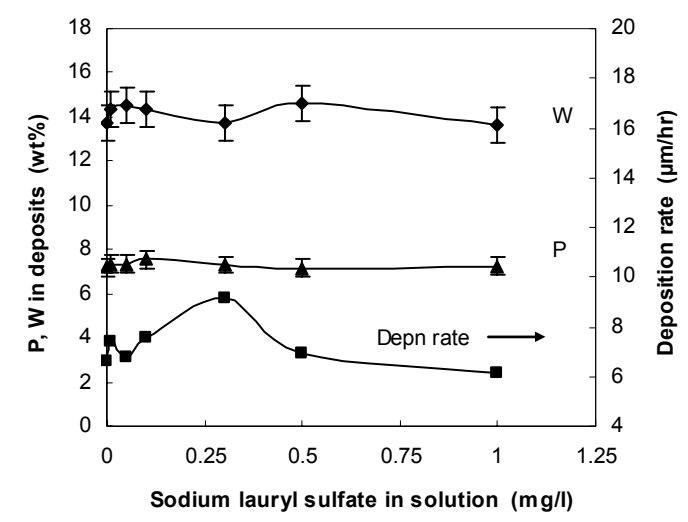

Figure 3: Effect of addition of SLS on the deposit composition and deposition rate of Ni-W-P from Solution A. $\mathrm{pH} 8.5,90^{\circ} \mathrm{C}$.

which is a commonly used pin-hole reliever in nickel electroplating, was added to the plating solution. It was found that after more than $0.3 \mathrm{mg} / 1$ SLS was added, the Ni-W-P obtained was largely compact and free of pores or pinholes. Figure 2(b) shows the surface morphology of such Ni-W-P coatings. A compositional analysis indicated that the addition of SLS up to $1 \mathrm{mg} / 1$ did not affect the deposit composition much, whilst the deposition rate 
seemed to have a maximum with the addition of 0.3 $\mathrm{mg} / 1 \mathrm{SLS}$ (Figure 3).

In order to obtain Ni-W-P with higher $\mathrm{W}$ content Solution B was employed [4]. It was found that although the deposits obtained from this bath contained about $21 \mathrm{wt} \% \mathrm{~W}$ and $7.6 \mathrm{wt} \% \mathrm{P}$, as compared to the maximum $\mathrm{W}$ content of $18 \mathrm{wt} \%$ achievable from Solution A, the corresponding deposition rate was as low as $\sim 1.5 \mu \mathrm{m}$ per hour.

\section{Liquid state interfacial reaction}

From the examination of the cross-section of NiW-P samples reacted with molten Sn-Bi solder at $200{ }^{\circ} \mathrm{C}$ for different periods of time, it was found that the substrate materials $(\mathrm{Cu}$ or $\mathrm{Al})$ did not have any appreciable effect on the barrier properties of $\mathrm{Ni}-\mathrm{W}-\mathrm{P}$. Whether deposited on $\mathrm{Al}$ or $\mathrm{Cu}$ (from the same solution), both types of Ni-W-P were found to have a similar composition (12-14 $\mathrm{wt} \% \mathrm{~W}$ and 7-8 $\mathrm{wt} \% \mathrm{P}$ ) and a similar thickness of approximately 10 $\mu \mathrm{m}$, and survived for more than 50 days of reaction with molten Sn-Bi solder. Failure was defined as the penetration of the molten solder to the substrate surface. For these samples, penetration of solder was not observed.

Amongst all of the plating conditions studied, including variations in the solution temperature, the position of samples in the solution (vertical or horizontal) and the addition of SLS, the $\mathrm{pH}$ value of the solution was found to have the most pronounced influence over the barrier properties of Ni-W-P. Penetration by molten solder of Ni-W-P deposited at pH 7 (approximately $13 \mu \mathrm{m}$ thickness) was observed after 16 days storage at $200{ }^{\circ} \mathrm{C}$. All other Ni-W-P samples with a similar thickness prepared with different parameters were not penetrated by molten $\mathrm{Sn}-\mathrm{Bi}$, even after 51 days storage. As expected, another factor which showed considerable effect on the barrier property of Ni-W-P was its thickness. For Ni-14\%W-7\%P (wt\%) coatings with a $5 \mu \mathrm{m}$ thickness, some of them were found to have been penetrated by Sn-Bi after 48 hours storage at $200{ }^{\circ} \mathrm{C}$, whilst coatings with a thickness greater than $12 \mu \mathrm{m}$ were still under test with no failure due to solder penetration observed after 51 days. The reflow temperature was also varied from $200{ }^{\circ} \mathrm{C}$ to $280{ }^{\circ} \mathrm{C}$ (all for 5 minutes), but no appreciable effect on the subsequent reaction behaviour of Ni-W-P has so far been observed.

Figure 4(a) shows the interfacial microstructure of Ni-3\%W-12\%P (wt\%) deposited from Solution A at $\mathrm{pH} 7$ and subsequently reacted with molten $\mathrm{Sn}-\mathrm{Bi}$ for 28 hours. Two new phases were formed between the Sn-Bi solder and the remaining unreacted Ni-W-
P. In contact with the solder was a layer of intermetallic compounds (IMC) which EDX identified as $\mathrm{Ni}_{3} \mathrm{Sn}_{4}$. Neither $\mathrm{W}$ nor $\mathrm{P}$ was detected in this $\mathrm{Ni}_{3} \mathrm{Sn}_{4}$. In between the $\mathrm{Ni}_{3} \mathrm{Sn}_{4}$ and the remaining Ni-W-P was a P-rich dark layer which had cracked and also contained small quantities of $\mathrm{W}$ (1 at $\%)$. The $\mathrm{P}$ content in this dark layer was about $28-30$ at $\%$, which is close to the stoichiometry of $\mathrm{Ni}_{3} \mathrm{P}(25$ at $\%)$. On binary Ni-P coatings reacted with solders, a similar P-rich layer has also been found and has been identified by TEM to be nanocrystalline $\mathrm{Ni}_{3} \mathrm{P}[8,9]$. Although no further experiment has been carried out to confirm the identity of this dark P-rich layer, it was assumed on the basis of composition similarity that this layer was also $\mathrm{Ni}_{3} \mathrm{P}$ as usually observed, but with $\mathrm{W}$ dissolution by means of substitution of $\mathrm{Ni}$ in the lattice, thus forming $(\mathrm{Ni}, \mathrm{W})_{3} \mathrm{P}$.

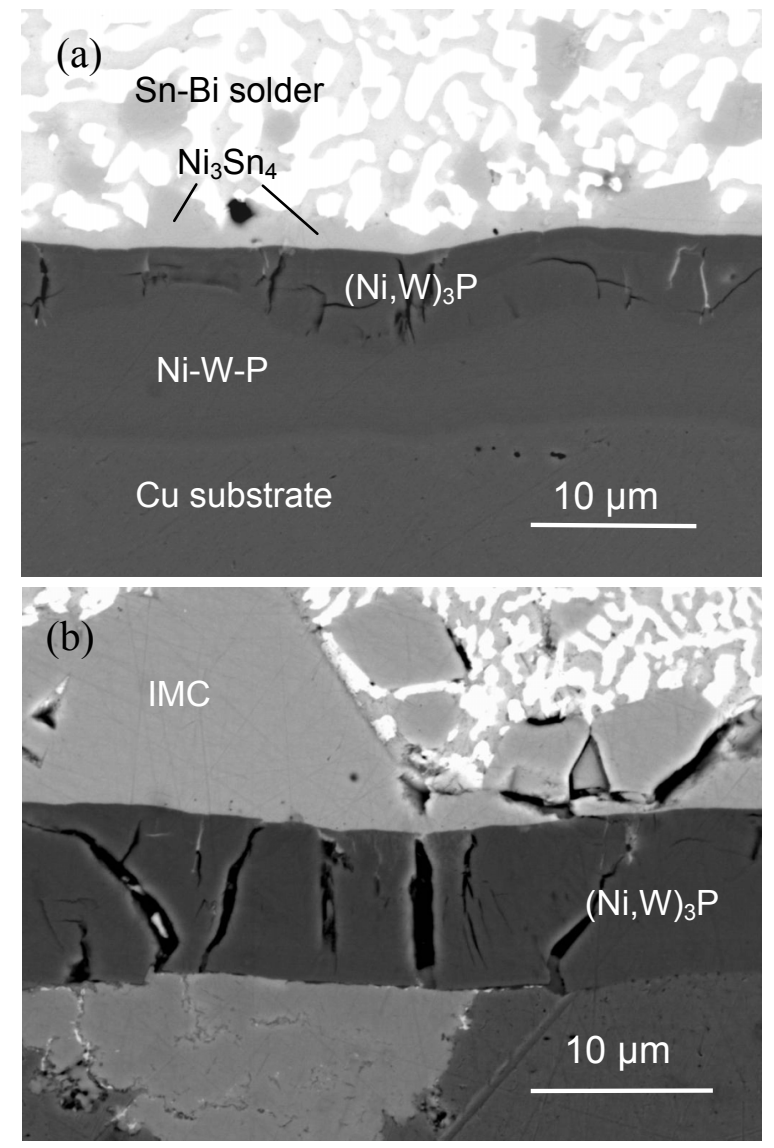

Figure 4: Interfacial microstructure of Ni-W-P deposited at $\mathrm{pH} 7$ after reaction with molten $\mathrm{Sn}-\mathrm{Bi}$ for (a) 28 hours and (b) 51 days.

From Figure 4(a) it can also be seen that although the interface between the $\mathrm{Ni}_{3} \mathrm{Sn}_{4}$ and $(\mathrm{Ni}, \mathrm{W})_{3} \mathrm{P}$ is relatively smooth, the interface between $(\mathrm{Ni}, \mathrm{W})_{3} \mathrm{P}$ and the remaining Ni-W-P is wavy. At some locations $(\mathrm{Ni}, \mathrm{W})_{3} \mathrm{P}$ had extended deeper into the NiW-P and it is thought that this eventually led to the early localized penetration of the coating by molten 
solder at such points when the reaction time was prolonged to 16 days. After a reaction time of 51 days, no original Ni-W-P was found and all of the coating had been completely transformed into $(\mathrm{Ni}, \mathrm{W})_{3} \mathrm{P}$, as shown in Figure $4(\mathrm{~b})$. The IMC at the interface was also found to have grown into coarse and faceted crystals.
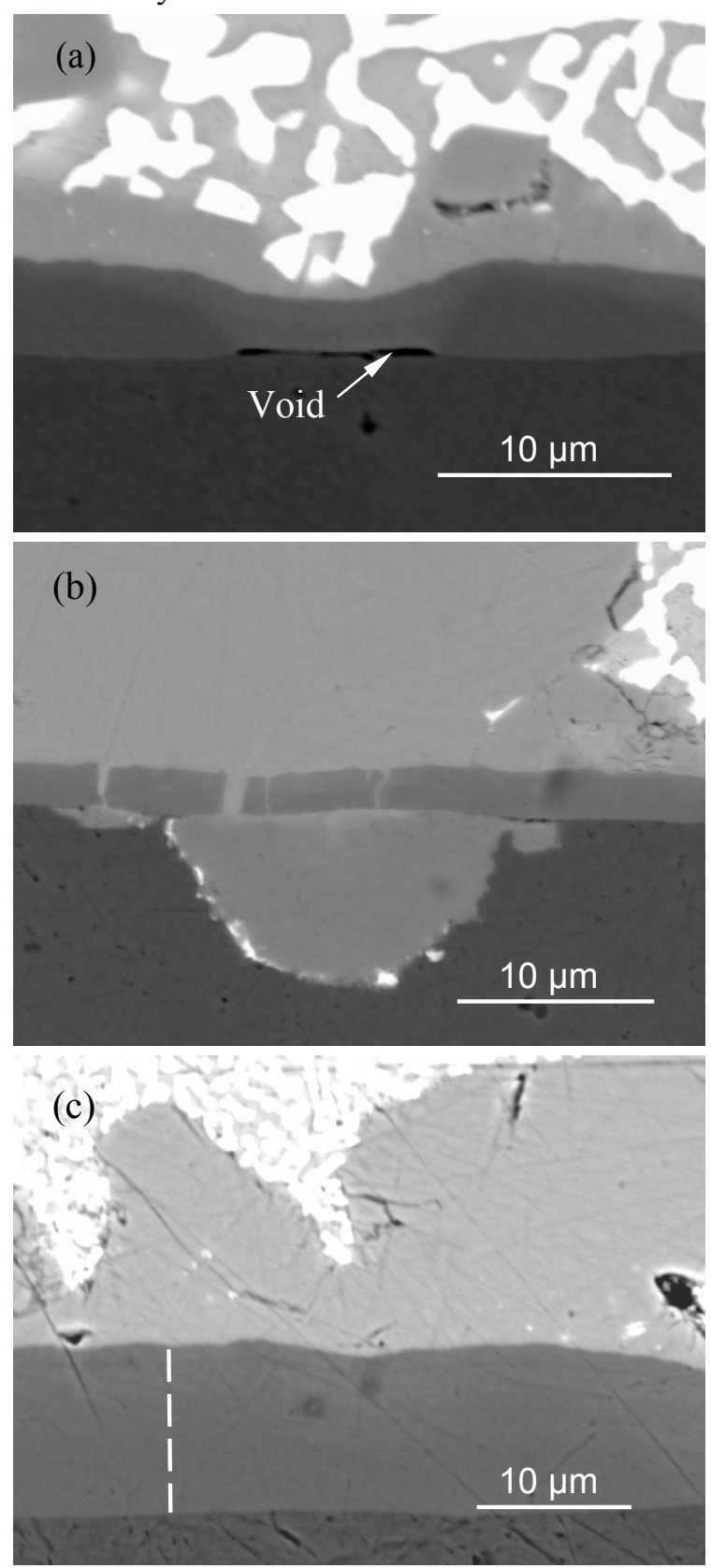

Figure 5: Interfacial microstructure of $\mathrm{Ni}-14 \% \mathrm{~W}-7 \% \mathrm{P}$ coatings (wt\%) deposited from Solution $\mathrm{A}$ at $\mathrm{pH} 8.5$ after reaction with molten Sn-Bi for (a) 28 hours; (b) 16 days; (c) 51 days. The original coating thickness was $5 \mu \mathrm{m}$ for

(a) and (b), and $13 \mu \mathrm{m}$ for (c). The substrate was $\mathrm{Cu}$.

For Ni-W-P coatings with higher $\mathrm{W}$ content which were deposited from Solution A at higher $\mathrm{pH}$ values, the interfacial microstructure after the liquid state solder reaction is shown in Figure 5. This high $\mathrm{W}$ coating (14 $\mathrm{wt} \% \mathrm{~W}$ and $7 \mathrm{wt} \% \mathrm{P})$ also suffered from preferred formation of $(\mathrm{Ni}, \mathrm{W})_{3} \mathrm{P}$ at some locations in the coating, as shown in Figure 5(a). However, the $(\mathrm{Ni}, \mathrm{W})_{3} \mathrm{P}$ formed in high $\mathrm{W}$ coatings was not cracked and it was greatly enriched in $\mathrm{W}$ in comparison to the $\mathrm{W}$ content of the remaining unreacted Ni-W-P. It is interesting to note that on areas where Ni-W-P had been completely reacted into $(\mathrm{Ni}, \mathrm{W})_{3} \mathrm{P}$, there was a void formed underneath between the $(\mathrm{Ni}, \mathrm{W})_{3} \mathrm{P}$ and the $\mathrm{Cu}$ substrate. Figure 5 (b) shows the penetration of the Ni-W-P coating with an original thickness of $5 \mu \mathrm{m}$ by molten solder after a reaction time of 16 days. Figure 5(c) shows that for the $\mathrm{Ni}-14 \% \mathrm{~W}-7 \% \mathrm{P}$ coating with an original thickness of $13 \mu \mathrm{m}$, no voids, cracks, or local penetration by solder had taken place even after a reaction time of 51 days at $200{ }^{\circ} \mathrm{C}$.

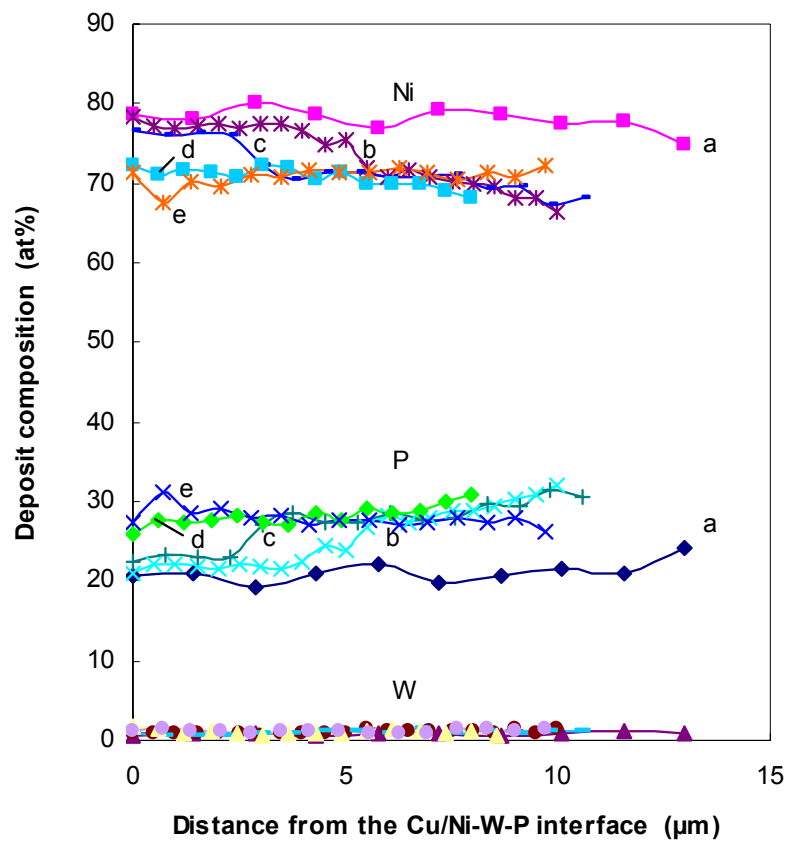

Figure 6: Line profiles of $\mathrm{Ni}, \mathrm{W}$, and $\mathrm{P}$ in Ni-W-P after reaction with molten $\mathrm{Sn}-\mathrm{Bi}$ for different periods of time. (a) as-plated; (b) 28 hrs; (c) 161 hrs; (d) 384 hrs; and (e) $1224 \mathrm{hrs}$.

In order to determine the changes in the distribution of $\mathrm{Ni}, \mathrm{W}$ and $\mathrm{P}$ in $\mathrm{Ni}-\mathrm{W}-\mathrm{P}$ with reaction time, EDX line scans were carried out across the thickness of the coating, as illustrated by the dotted line in Figure 5(c). The results for Ni-W-P deposited from Solution $\mathrm{A}$ at $\mathrm{pH} 7$ with an original thickness of approximately $13 \mu \mathrm{m}$ are shown in Figure 6. It can be seen that with increasing reaction time, the $(\mathrm{Ni}, \mathrm{W})_{3} \mathrm{P}$, which exhibited a $\mathrm{P}$ content of about 28 30 at $\%$, became thicker and after 384 hours (16 days), all of the as-plated Ni-W-P coating had gone and only the $(\mathrm{Ni}, \mathrm{W})_{3} \mathrm{P}$ was left behind. 


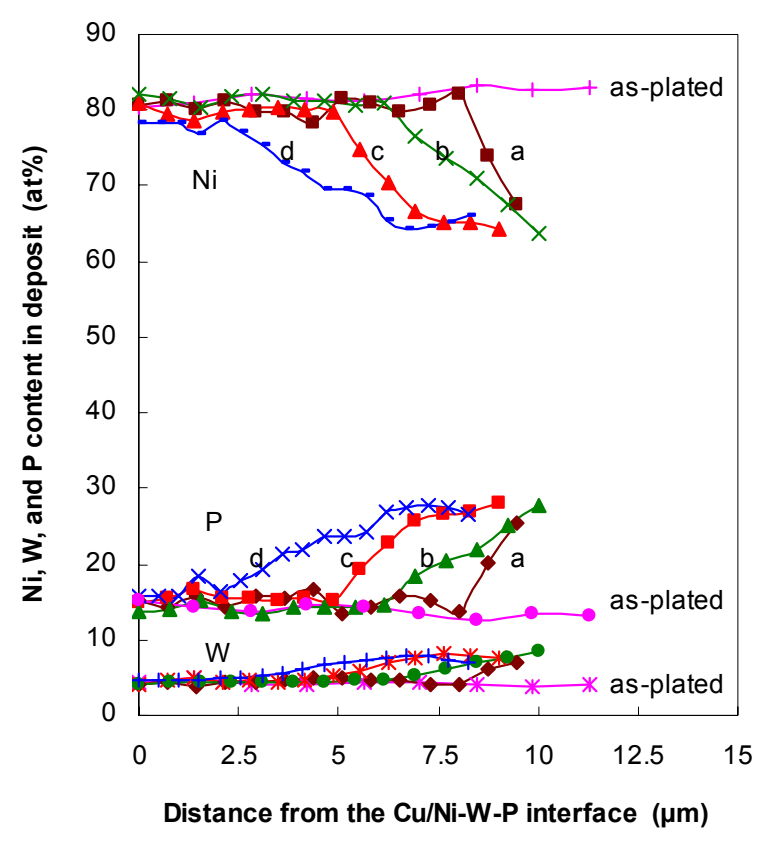

Figure 7: Line profiles of Ni, W, and $\mathrm{P}$ in Ni-W-P after reacted with molten $\mathrm{Sn}-\mathrm{Bi}$ for different periods of time. (a) $28 \mathrm{hrs}$; (b) $161 \mathrm{hrs;} \mathrm{(c)} 384 \mathrm{hrs;} \mathrm{and} \mathrm{(d)} 1224 \mathrm{hrs}$. The Ni-W-P was deposited from Solution A at $\mathrm{pH}$ 8.5.

The as-plated thickness was approximately $13 \mu \mathrm{m}$.

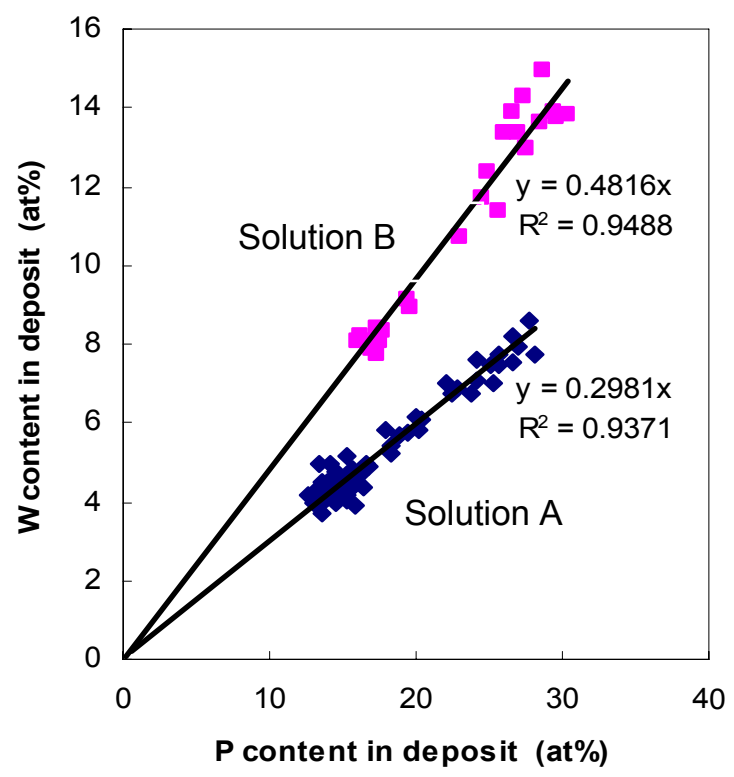

Figure 8: Relationship between the $\mathrm{P}$ and $\mathrm{W}$ contents in both the $(\mathrm{Ni}, \mathrm{W})_{3} \mathrm{P}$ and the unreacted $\mathrm{Ni}-\mathrm{W}-\mathrm{P}$ during the liquid state interfacial reaction with molten solder.

For the Ni-W-P coatings with higher $\mathrm{W}$ content, the line profiles of $\mathrm{Ni}, \mathrm{W}$ and $\mathrm{P}$ shown in Figure 7 indicated that due to the high initial $\mathrm{W}$ in the asplated Ni-W-P, a noticeable enrichment of W occurred at the reaction front. Unlike the low W electroless Ni-W-P deposited at $\mathrm{pH} 7$, which had a relatively sharp interface with the $(\mathrm{Ni}, \mathrm{W})_{3} \mathrm{P}$ (Figure 6), the high $\mathrm{W}$ electroless Ni-W-P exhibited an interface with the $(\mathrm{Ni}, \mathrm{W})_{3} \mathrm{P}$ that extended for as much as $4 \mu \mathrm{m}$. The observed spreading of the interface is not thought to be caused by the spatial resolution of EDX, which is normally within the range of 1-2 $\mu \mathrm{m}$. It can also be seen from Figure 7 that the $\mathrm{W}$ and $\mathrm{P}$ contents in $(\mathrm{Ni}, \mathrm{W})_{3} \mathrm{P}$ didn't continuously increase. Instead they became stabilized at a particular value. The $\mathrm{P}$ content stopped increasing after it reached approximately 28-30 at\%., whilst the maximum $W$ content observed in the $(\mathrm{Ni}, \mathrm{W})_{3} \mathrm{P}$ was found to be dependent on the initial $\mathrm{W}$ content in the as-plated Ni-W-P coating. For Ni-W-P deposited from Solution A, the maximum $\mathrm{W}$ content obtained in $(\mathrm{Ni}, \mathrm{W})_{3} \mathrm{P}$ was about 8 at $\%$ (or $22 \mathrm{wt} \%$ ). For Ni-W-P from Solution $\mathrm{B}$, the maximum $\mathrm{W}$ content obtained in $(\mathrm{Ni}, \mathrm{W})_{3} \mathrm{P}$ was about $15 \mathrm{at} \%$ (or $42 \mathrm{wt} \%$ ).

By plotting the $\mathrm{W}$ content against the $\mathrm{P}$ content obtained from the line scans, it was found that during the interfacial reaction, the ratio of $\mathrm{W}$ to $\mathrm{P}$ in the $(\mathrm{Ni}, \mathrm{W})_{3} \mathrm{P}$ remained the same as that for the unreacted Ni-W-P. This result is interesting and it reveals some important information on the reaction mechanism between Ni-W-P and molten Sn-Bi solder. The enrichment of $\mathrm{W}$ and $\mathrm{P}$ in the reaction front could be caused by two processes: (1) the diffusion of $\mathrm{Ni}$ from the unreacted Ni-W-P through the $(\mathrm{Ni}, \mathrm{W})_{3} \mathrm{P}$ layer, (2) the decomposition of $(\mathrm{Ni}, \mathrm{W})_{3} \mathrm{P}$ at the $\mathrm{Ni}_{3} \mathrm{Sn}_{4} /(\mathrm{Ni}, \mathrm{W})_{3} \mathrm{P}$ interface and the subsequent back diffusion of $\mathrm{W}$ and $\mathrm{P}$ towards the unreacted Ni-W-P. However, due to their large difference in melting point and diffusivity, it is expected that $\mathrm{W}$ would diffuse much slower than $\mathrm{P}$ in $(\mathrm{Ni}, \mathrm{W})_{3} \mathrm{P}$. An interfacial reaction proceeding according to the second approach would lead to a change in the molar ratio between $\mathrm{W}$ and $\mathrm{P}$, which is contradictory to the results shown in Figure 8. Therefore, it is most likely that the reaction between Ni-W-P and molten Sn-Bi solder has taken place by the diffusion of $\mathrm{Ni}$ only and no diffusion of $\mathrm{W}$ or $\mathrm{P}$ was involved. This mechanism is reasonable as it can also explain the formation of voids at the $\mathrm{Cu} /(\mathrm{Ni}, \mathrm{W})_{3} \mathrm{P}$ interface. Since Ni is the only diffusion element, its unbalanced diffusion towards the $\mathrm{Ni}_{3} \mathrm{Sn}_{4} /(\mathrm{Ni}, \mathrm{W})_{3} \mathrm{P}$ interface would be accompanied by the generation of vacancy sites in the unreacted NiW-P, which would then diffuse in the opposite direction to the Ni. Once all of the Ni-W-P was transformed into $(\mathrm{Ni}, \mathrm{W})_{3} \mathrm{P}$, these vacancies could coalesce at the $\mathrm{Cu} /(\mathrm{Ni}, \mathrm{W})_{3} \mathrm{P}$ interface thus leading to the formation of voids. It is necessary to point out that the formation of voids at the $\mathrm{Cu} /(\mathrm{Ni}, \mathrm{W})_{3} \mathrm{P}$ interface (Figure 5(a)) may also be due to the 
dewetting of $(\mathrm{Ni}, \mathrm{W})_{3} \mathrm{P}$ from the $\mathrm{Cu}$ substrate surface.

It was found that the $\mathrm{W}$ content reached a level of as high as $15 \mathrm{at} \%$ (or $42 \mathrm{wt} \%$ ) in $(\mathrm{Ni}, \mathrm{W})_{3} \mathrm{P}$ for the Ni-W-P coating deposited from Solution B. However, such coatings with an initial thickness of $\sim 6 \mu \mathrm{m}$ were found to have been penetrated by molten solder after 16 days at $200{ }^{\circ} \mathrm{C}$. The thin layer of $(\mathrm{Ni}, \mathrm{W})_{3} \mathrm{P}$ (approximately $2.5 \mu \mathrm{m}$ ) left behind after the complete consumption of the original Ni-W-P failed to act as a barrier layer. Therefore, a combination of high $\mathrm{W}$ content and high thickness of Ni-W-P is necessary for achieving a long barrier metallization lifetime.

From the examination of the penetration site, it was believed that the penetration of Ni-W-P was not due to the diffusion of $\mathrm{Sn}$ atoms through the $(\mathrm{Ni}, \mathrm{W})_{3} \mathrm{P}$. No Sn was detected in the $(\mathrm{Ni}, \mathrm{W})_{3} \mathrm{P}$ even if it was penetrated. The penetration probably took place as the $(\mathrm{Ni}, \mathrm{W})_{3} \mathrm{P}$ was cracked from the tensile stress generated in $(\mathrm{Ni}, \mathrm{W})_{3} \mathrm{P}$ due to the volume shrinkage accompanying the transformation of $\mathrm{Ni}$ $\mathrm{W}-\mathrm{P}$ into $(\mathrm{Ni}, \mathrm{W})_{3} \mathrm{P}$. Further work is needed to look into the detailed failure mechanism of Ni-W-P coatings on reaction with molten solder.

\section{Conclusions}

The deposition and the reaction behaviour of electroless Ni-W-P coatings with molten Sn-Bi solder were studied. It was found that the $\mathrm{pH}$ value has the most significant influence over the $\mathrm{W}$ and $\mathrm{P}$ content in the deposit. During the reaction with molten solder, the major IMC formed at the interface was $\mathrm{Ni}_{3} \mathrm{Sn}_{4}$. W and $\mathrm{P}$ was found to become enriched in a layer having a composition similar to the stoichiometry of $\mathrm{Ni}_{3} \mathrm{P}$. The ratio of $\mathrm{W}$ to $\mathrm{P}$ in the $(\mathrm{Ni}, \mathrm{W})_{3} \mathrm{P}$ layer remained unchanged during the interfacial reaction, suggesting that $\mathrm{Ni}$ was the only element to have diffused outward to sustain the interfacial reaction and the formation of $\mathrm{Ni}_{3} \mathrm{Sn}_{4}$. The tungsten content and the thickness of Ni-W-P were identified as the two key parameters that govern the barrier properties. As thin Ni-W-P was completely consumed by the interfacial reaction, voids were found at the $\mathrm{Cu} /(\mathrm{Ni}, \mathrm{W})_{3} \mathrm{P}$ interface. It was believed that $(\mathrm{Ni}, \mathrm{W})_{3} \mathrm{P}$ was in a tensile stress state. Too thin a layer of $(\mathrm{Ni}, \mathrm{W})_{3} \mathrm{P}$ may be cracked by the stress. The penetration of molten solder following these cracks was thought to be responsible for the failure of the barrier metallization.

\section{Acknowledgments}

This research was funded by the Engineering and Physical Science Research Council (Grant Ref. GR/S87485/01) in collaboration with Dynex
Semiconductor Ltd., TWI Ltd., Schlumberger, Henkel Ltd. and Oxford Applied Technology Ltd.

\section{References}

1. Nowottnick, M., Pape, U., Wittke, K., Scheel, W., "Solder joints for high temperature electronics," SMTA International Conf. Proc., Chicago, IL, Sept. 21-25, 2003, pp.693-699.

2. Li, J.F., Mannan, S.H., Clode, M.P., Lobato, H.M., Liu, C., Whalley, B.C., Lawrence, F.T., Steen, H., "Interactions between liquid $\mathrm{Sn}-\mathrm{Bi}$ based solders and contact metals for high temperature applications," Proc. 55 IEEE Electronic Components and Technology Conf. (ECTC'55), Lake Buena Vista, FL USA, 31st May 2005, pp 441-448.

3. Mannan, S.H., Clode, M.P., "Materials and processes for implementing high-temperature liquid interconnects," IEEE Trans. On Adv. Packaging, Vol. 27, No. 3 (2004), pp. 508-514

4. Pearlstein, F., Weightman, R.F., "Electroless Deposition of Nickel Alloys," Electrochem. Technol., Vol. 6, No. 11-12 (1968), pp. 427-430.

5. Gawrilov, G.G., Chemical (Electroless) Nickelplating, Portcullis Press, (Redhill 1979), pp. 115-116

6. Chen, K., Liu, C., Whalley, D.C., Hutt, D.A., "Molten Solder Interconnects II: Reactions Between Ni Substrates and Sn-Bi Based Solders," $6{ }^{\text {th }}$ International Conference on High Temperature Electronics (HITEN'2005), Paris, France, September, 2005.

7. Aoki, K. and Takano, O., "Electrical Resistance of Electroless Nickel-Tungsten-Phosphorus Alloy Deposits", Plat. Surf. Finish., Vol. 77, No. 3 (1990), pp. $48-52$.

8. Jang, J.W., Kim, P.G., Tu, K.N., Frear, D.R., Thompson, P., "Solder reaction-assisted crystallistion of electroless Ni-P under bump metallization in low cost flip chip technology," J. Appl. Phys., Vol. 85, No. 12 (1999), pp. 8456-8463.

9. Jang, J.W., Frear, D.R., Lee, T.Y., Tu, K.N., "Morphology of interfacial reaction between lead-free solders and electroless Ni-P under bump metallization," J. Appl. Phys., Vol. 88, No. 11 (2000), pp.6359-6363. 